\title{
Influence of household demographic and socio-economic factors on household expenditure on tobacco in six New Independent States Mamuka Djibuti*1,2, George Gotsadze1, George Mataradze ${ }^{2}$ and
} Akaki Zoidze ${ }^{1}$

Address: ${ }^{1}$ Curatio International Foundation, Tbilisi, Georgia and ${ }^{2}$ Department of Public Health, Tbilisi State Medical University, Georgia Email: Mamuka Djibuti* - m.djibuti@curatio.com; George Gotsadze - g.gotsadze@curatio.com; George Mataradze - khalampre@yahoo.com; Akaki Zoidze - k.zoidze@curatio.com

* Corresponding author

Published: 30 August 2007

BMC Public Health 2007, 7:222 doi:10.1 186/147/-2458-7-222
Received: 7 December 2006

Accepted: 30 August 2007

This article is available from: http://www.biomedcentral.com/I47I-2458/7/222

(C) 2007 Djibuti et al; licensee BioMed Central Ltd.

This is an Open Access article distributed under the terms of the Creative Commons Attribution License (http://creativecommons.org/licenses/by/2.0), which permits unrestricted use, distribution, and reproduction in any medium, provided the original work is properly cited.

\begin{abstract}
Background: To identify demographic and socio-economic factors that are associated with household expenditure on tobacco in Azerbaijan, Georgia, Kazakhstan, Kyrgyzstan, Russian Federation, and Tajikistan.

Methods: Secondary analysis of the data available through the World Bank Living Standards Monitoring Survey conducted in aforementioned countries in 1995-2000. The role of different variables (e.g. mean age of household members, household area of residence, household size, share of adult males, share of members with high education) in determining household expenditure on tobacco (defined as tobacco expenditure share out of total monthly $\mathrm{HH}$ consumption) was assessed by using multiple regression analysis.

Results: Significant differences were found between mean expenditure on tobacco between rich and poor - in absolute terms the rich spend significantly more compared with the poor. Poor households devote significantly higher shares of their monthly $\mathrm{HH}$ consumption for tobacco products. Shares of adult males were significantly associated with the share of household consumption devoted for tobacco. There was a significant negative association between shares of persons with tertiary education within the $\mathrm{HH}$ and shares of monthly household consumption devoted for tobacco products. The correlation between household expenditures on tobacco and alcohol was found to be positive, rather weak, but statistically significant.

Conclusion: Given the high levels of poverty and high rates of smoking in the New Independent States, these findings have important policy implications. They indicate that the impact and opportunity costs of smoking on household finances are more significant for the poor than for the rich. Any reductions in smoking prevalence within poor households could have a positive economic impact.
\end{abstract}

\section{Background}

In the New Independent States (NIS), there has been a marked socio-economic and structural change, which fol- lowed the end of the socialist regime in 1989 and 1992, and the subsequent attempt of transition to a market economy. This period was characterized by steady 
increase in poverty in all transition countries - with dramatic increase in some. Countries like, Azerbaijan, Georgia, Kyrgyz Republic and Tajikistan are now among the poorest in the region [1].

Smoking may have serious implications for poverty. The opportunity cost of money spent on cigarettes is obviously higher for people living on low incomes - saving money spent on tobacco products could help feed families [2]. Data from various countries clearly show that tobacco is often a significant part of family expenditures [3-6].

According to the results of recent studies, smoking rates among men in the Former Soviet Union are very high and that female rates, while yet low, appear to be increasing [7-10]. Namely, smoking rates in men in the six NIS countries of interest vary from $50 \%$ to $65 \%$ and rates in women from $2 \%$ to $16 \%$ [11].

The aim of the proposed study was to assess the economic burden of smoking at a HH level in six NIS countries (Azerbaijan, Georgia, Kazakhstan, Kyrgyzstan, Russian Federation, and Tajikistan), using Living Standard Monitoring Survey (LSMS) data sets and thereby to provide information critical to the development of a tobacco control policy.

\section{Methods}

\section{Design and data sources}

The basic design of the study has been secondary analysis of the data available through World Bank LSMS. LSMS data files and necessary supporting documentation (survey instruments and questionnaires) were obtained for all six countries. The year of LSMS and $\mathrm{HH}$ count included into the survey are as follows: Azerbaijan - 1995/2,000; Georgia - 1999/3,300; Kazakhstan 1996/2,000; Kyrgyzstan - 1998/3,000; Russian Federation - 2000/4,000; Tajikistan - 1999/2,000.

In each of these six countries, LSMS collected data on household demographic, economic and social characteristics, namely a) number, age, and sex of $\mathrm{HH}$ members; b) education level of HH members; c) employment status of HH members; d) HH monthly expenditure on tobacco; e) $\mathrm{HH}$ monthly expenditure on alcohol; f) $\mathrm{HH}$ monthly expenditure on food; and g) $\mathrm{HH}$ total monthly expenditures.

All data on expenditures were collected at $\mathrm{HH}$ (and not at individual) level, which made us decide to use $\mathrm{HH}$ as the unit of analysis. Other socio-demographic data were collected at the individual level. Thus to be able to conduct $\mathrm{HH}$ level analysis, it was necessary to construct composite variables - socio-demographic indexes, details on which are given in the text below.

\section{Variables}

To investigate differences in $\mathrm{HH}$ expenditure on tobacco between rich and poor households, we have developed a composite measure, the HH Poverty index. HHs in each country were divided into 5 equal groups based on their monthly total per capita expenditure (population expenditure quintiles). Households belonging to the lowest expenditure quintile were classified as "poor" and households belonging to the highest expenditure quintile were classified as "rich".

It should be said that the measurement of per capita expenditures rules out the possibility to attach different economies of scale to households of different types [12]. Economies of scale arise in many ways - for example, by sharing certain expenditures such as expenditures on housing, utilities, cars, etc. Apart from household size, the age or gender of household members may also influence the amount of consumption, for example food. Other judgments may be used, as a result a wide variety of equivalence scales are used in various countries, and there is no accepted equivalence scale in the FSU [13-16]. Hence, we used per capita expenditure measure - by far the most widespread rule applied in practice, which assumes that all family members receive the same fraction of household expenditures [17]. Before deciding to proceed with this approach, however, we conducted sensitivity tests by using different scales according to the methodology adopted by The World Bank [18], which revealed no significant variations in the household mean expenditures on tobacco by expenditure quintile groups.

To investigate variations in $\mathrm{HH}$ expenditure on tobacco by $\mathrm{HH}$ structure, i.e. number, age, gender, employment, and education level of $\mathrm{HH}$ members, we have defined the following composite variables - socio-demographic indexes: a) HH Size Index - number of HH members; b) HH Adult Index - share of 15 to 65 year old people in a $\mathrm{HH}$; c) $\mathrm{HH}$ Elderly Index - share of people age more than 65 years in a $\mathrm{HH}$; d) HH Children Index - share of children under 15 years of age in a $\mathrm{HH}$; e) $\mathrm{HH}$ Adult Female Index - share of adults 15 to 65 year old females in a $\mathrm{HH}$; f) $\mathrm{HH}$ Adult Male Index - share of adults 15 to 65 year old males in a $\mathrm{HH}$; g) $\mathrm{HH}$ Gender Index - HH adults 15 to 65 year old female/male ratio; h) HH Employment Index - share of $\mathrm{HH}$ members in permanent employment; and f) $\mathrm{HH}$ Education Index - share of $\mathrm{HH}$ members with high (university) education.

\section{Statistical analysis}

Expenditure on tobacco (both mean and total) was calculated for each expenditure quintile group separately. For 
comparison of the mean expenditure on tobacco between groups we used analysis of variance (ANOVA). For comparison of urban vs. rural differences in the mean expenditures on tobacco by expenditure groups we used Student's t test.

Tobacco expenditure was also calculated as a proportion of $\mathrm{HH}$ total monthly spending for each household and the mean percentage in each expenditure group was then calculated. The mean expenditure share (\%) between expenditure groups was then compared using analysis of variance (ANOVA). Similar analysis between different expenditure groups was done for urban and rural HHs separately. For evaluating urban versus rural differences by expenditure groups we used Student's t test.

Association between $\mathrm{HH}$ expenditure on tobacco and alcohol was explored by estimating Pearson's correlation coefficient between $\mathrm{HH}$ expenditure on alcohol and tobacco as absolute expenditures. Azerbaijan was excluded from this analysis given that there was no separate data on $\mathrm{HH}$ expenditure on tobacco and alcohol.

Association between HH socio-demographic indexes and $\mathrm{HH}$ expenditure on tobacco as proportion of total monthly $\mathrm{HH}$ consumption was explored by using univariate linear regression analysis. In addition to aforementioned indexes, in the models of each country we included the variables such as $\mathrm{HH}$ per capita total monthly spending and $\mathrm{HH}$ area of residence.

In order to define the socio-demographic factors/indexes that are independently associated with high share of HH's expenditure on tobacco, we constructed multiple linear regression models. In the model for all countries, we entered the variables that proved to be significant in the univariate analysis. We did not include those variables that strongly correlated with each other to avoid the effect of colinearity. In order to reduce the chance of type I error due to a high number of significance testing, all $\mathrm{p}$ values were set to $<0.01$.

\section{Results \\ Variation in $\mathrm{HH}$ expenditure on tobacco by $\mathrm{HH}$ economic index}

In all six countries significant differences were found between mean expenditure on tobacco between rich and poor - namely, the rich spend significantly more compared with poor (Table 1).

As for urban vs. rural differences in the mean expenditures on tobacco by expenditure groups, it was found that among the poor, those living in rural areas had higher expenditures compared with those living in urban places, and this was true for all countries except Azerbaijan. The opposite trend was found among the rich, namely, those living in urban areas had higher expenditures on tobacco. It should be said, however, that these differences were statistically significant for Georgia and Kyrgyzstan only. Russia LSMS did not provide data on urban/rural affiliation of HHs. Therefore, we could not assess urban vs. rural differences in $\mathrm{HH}$ expenditures on tobacco.

As can be seen from Table 2, poor HHs have significantly higher expenditures on tobacco as proportion of total monthly HH outgoings in all countries excluding Georgia and Azerbaijan.

When we did separate analysis to compare tobacco expenditure shares between urban and rural HHs by expenditure quintile groups, it was found that rich $\mathrm{HHs}$ living in urban areas spend significantly higher portion of their monthly total spending on tobacco compared with rich HHs residing in rural areas (the difference was statistically significant for Georgia, Kazakhstan, and Kyrgyzstan). Differences between urban and rural HHs belonging to the poorest groups was not significant in any of these countries. Once again this analysis could not be conducted for Russia as no data on urban/rural status was provided.

\section{The association between $\mathrm{HH}$ expenditure on tobacco and alcohol}

The correlation between absolute expenditures on tobacco and alcohol was found to be positive, rather weak, but statistically significant in all five countries (Pearson's r being 0.145, 0.201, 0.106, 0.204, and 0.304 for Georgia, Kazakhstan, Kyrgyzstan, Russia, and Tajikistan, respectively; $\mathrm{p}<0.01$ for all countries) indicating that HHs that spend more on tobacco are also likely to spend more on alcohol.

\section{The factors independently associated with high share of $\mathrm{HH}$ 's expenditure on tobacco}

All variables (per capita monthly total spending, $\mathrm{HH}$ area of residence, mean age of $\mathrm{HH}$ members plus all sociodemographic indexes as described above) were included in univariate linear regression analysis for each country. Variables that proved to be significantly associated with the dependent variables (tobacco expenditures share on total monthly spending) were then entered in multiple linear regression models. Table 3 presents only those variables that were significantly associated with the dependent variable in five countries. In Azerbaijan, none of the variables had significant association with the dependent variable (tobacco \& alcohol expenditure share on total monthly spending).

Adult male's share was significantly associated with tobacco expenditure share in all countries (except Geor- 
Table I: Mean expenditure on tobacco by HHs per month (in national currency)

\begin{tabular}{|c|c|c|c|c|c|c|}
\hline $\begin{array}{l}\text { Expenditure } \\
\text { group }\end{array}$ & $\begin{array}{l}\text { Azerbaijan } \\
\text { (AZM) }\end{array}$ & Georgia (GEL) & $\begin{array}{l}\text { Kazakhstan } \\
\text { (KZT) }\end{array}$ & $\begin{array}{l}\text { Kyrgyzstan } \\
\text { (KGS) }\end{array}$ & Russia (RUB) & Tajikistan (TJS) \\
\hline Poor & $4,510.0$ & 1.9 & 73.1 & 2.7 & 18.5 & 254.4 \\
\hline 2 & $10,676.7$ & 7.7 & 125.0 & 4.8 & 35.5 & 347.5 \\
\hline 3 & $16,609.1$ & 15.0 & 190.1 & 6.1 & 57.2 & 491.5 \\
\hline 4 & $21,904.7$ & 27.7 & 242.5 & 9.1 & 89.0 & 683.8 \\
\hline Rich & $48,366.7$ & 57.0 & 361.8 & 13.3 & 141.6 & 1378.3 \\
\hline Total & 20413 & 22.4 & 198.5 & 7.2 & 68.4 & 631.0 \\
\hline $\mathbf{F}$ & 48.8 & 100.2 & 44.39 & 51.96 & 117.2 & 17.53 \\
\hline Sig. & 0.000 & 0.000 & 0.000 & 0.000 & 0.000 & 0.000 \\
\hline
\end{tabular}

GEL, Georgian Lari; KZT, Kazakhstan Tenge; TJS, Tajikistan Somoni; KGS, Kyrgyzstan Som; AZM, Azerbaijan Manat; RUB, Russian Rouble.

gia, where adult female's share emerged as independent positive predictors). Urban area of residence emerged as independent predictor for higher expenditure share on tobacco in Kyrgyzstan only. Share of employed persons in a HH was independently associated with higher expenditure share on tobacco only in Kazakhstan.

It should be stressed that all models explained from 1.5 to $6 \%$ of the variance of the tobacco expenditure share, which indicates the limitation of these constructed models.

\section{Discussion}

A major limitation of the study has been that Azerbaijan LSMS collected data on $\mathrm{HH}$ expenditures on tobacco aggregated with expenditures on alcohol, and there was no way to disaggregate these data. Therefore, results of the analysis of Azerbaijan data should be interpreted with some caution. In Georgia, LSMS data was obtained from the local State Department of Statistics (and not from the World Bank as was done for other countries), which raises concern with regard to data validity considering that the data set has not probably gone through careful quality checking procedures.

Results of this analysis clearly indicate that tobacco use poses greater economic burden on poor HHs in Russia, Kazakhstan, Tajikistan, and Kyrgyzstan where tobacco expenditure share on HH's total monthly spending among poor is $2.75 \%, 2.47 \%, 1.32 \%$, and $0.53 \%$, respectively. Further research is needed to disclose the factors determining these differences in various countries. The opposite findings for Georgia and Azerbaijan confirm the authors concern with regard to the validity of Georgian LSMS data and the above statement that the data for Azerbaijan should be interpreted with some caution, since expenditures on tobacco and alcohol are pooled together.

Situation in regard with HH tobacco expenditures share out of the total expenditure seems to be comparable or slightly better in NIS compared with other countries: in the Bangladesh survey, on average for poor $\mathrm{HHs}, 2.46 \%$ of total expenditures were allocated for tobacco products [5]. In Sri Lanka, the poorest households spent an average of just over $3 \%$ of total expenditures on tobacco products [4]. In Bulgaria, the low and lower-middle income group spent about $4.9 \%$ of total income on cigarettes [6]. Nevertheless, tobacco expenditure share is still high and may exacerbate the effects of poverty and cause significant deterioration in living standards among the poor.

The fact that adult males share was significantly associated with tobacco expenditure is in line with the results of studies evaluating patterns of smoking in the former Soviet Union [7-9,11,19], where smoking was more common among males of all ages and areas.

Table 2: Expenditure on tobacco as proportion (\%) of HH's total monthly spending by countries

\begin{tabular}{|c|c|c|c|c|c|c|c|}
\hline $\begin{array}{l}\text { Expenditure } \\
\text { group }\end{array}$ & & Azerbaijan & Georgia & Kazakhstan & Kyrgyzstan & Russia & Tajikistan \\
\hline Poor & & 3.28 & 1.54 & 2.47 & 0.53 & 2.75 & 1.32 \\
\hline & 2 & 3.43 & 1.89 & 1.67 & 0.49 & 2.08 & 0.79 \\
\hline & 3 & 3.67 & 1.99 & 1.63 & 0.43 & 2.06 & 0.78 \\
\hline & 4 & 3.31 & 2.01 & 1.41 & 0.42 & 2 & 0.77 \\
\hline Rich & & 3.66 & 1.79 & 1.19 & 0.31 & 1.4 & 0.78 \\
\hline Total & & 3.47 & 1.85 & 1.67 & 0.43 & 2.06 & 0.89 \\
\hline $\mathbf{F}$ & & 0.39 & 1.092 & 6.44 & 5.19 & 10.59 & 3.34 \\
\hline Sig & & 0.82 & 0.359 & 0.000 & 0.000 & 0.000 & 0.01 \\
\hline
\end{tabular}


Table 3: Results from Multiple Linear Regressions for 5 countries - Dependent Variable: tobacco expenditure share out of total monthly spending

\begin{tabular}{|c|c|c|c|}
\hline Country/Independent Variable & $\begin{array}{c}\text { Regression coefficient (95\% } \\
\text { CI) }\end{array}$ & p Value & Adjusted $\mathbf{R}^{2}$ \\
\hline \multicolumn{4}{|l|}{ Georgia } \\
\hline Mean age of $\mathrm{HH}$ members & $-0.020(-0.032$ to 0.008$)$ & 0.001 & 0.039 \\
\hline Adult females ( 15 to 65 ) share out of total number of $\mathrm{HH}$ members & $0.024(0.016$ to 0.031$)$ & 0.000 & \\
\hline Adult males ( 15 to 65 ) share out of total number of $\mathrm{HH}$ members & $-0.012(-0.019$ to $-0 / 005)$ & 0.001 & \\
\hline \multicolumn{4}{|l|}{ Kazakhstan } \\
\hline HH per capita total monthly spending & $-0.000(0.000$ to 0.000$)$ & 0.000 & 0.045 \\
\hline Adult males ( 15 to 65 ) share out of total number of $\mathrm{HH}$ members & $0.029(0.02$ to 0.036$)$ & 0.000 & \\
\hline \multicolumn{4}{|l|}{ Kyrgyzstan } \\
\hline Adult females ( 15 to 65 ) share out of total number of $\mathrm{HH}$ members & $-0.003(-0.004$ to 0.001$)$ & 0.003 & 0.037 \\
\hline Adult males ( 15 to 65 ) share out of total number of $\mathrm{HH}$ members & $0.007(0.005$ to 0.009$)$ & 0.000 & \\
\hline Share of employed plus self employed out of total HH members & $0.002(0.001$ to 0.003$)$ & 0.003 & \\
\hline Share of persons with high education out of total $\mathrm{HH}$ members & $-0.003(-0 / 004$ to $-0.00 \mathrm{I})$ & 0.004 & \\
\hline \multicolumn{4}{|l|}{ Tajikistan } \\
\hline Adult males ( 15 to 65 ) share out of total number of $\mathrm{HH}$ members & 0.015 (0.006 to 0.022$)$ & 0.000 & 0.015 \\
\hline \multicolumn{4}{|l|}{ Russia } \\
\hline Mean age of $\mathrm{HH}$ members & $-0.021(-0.027$ to -0.012$)$ & 0.000 & 0.06 \\
\hline HH per capita total monthly spending & $-0.000(0.000$ to 0.000$)$ & 0.000 & \\
\hline Adult males ( 15 to 65 ) share out of total number of $\mathrm{HH}$ members & $0.032(0.026$ to 0.038$)$ & 0.000 & \\
\hline Share of persons with high education out of total $\mathrm{HH}$ members & $-0.010(-0 / 015$ to $-0 / 005)$ & 0.000 & \\
\hline
\end{tabular}

There was significant negative association between share of persons with university education and tobacco expenditure share in Kazakhstan, Kyrgyzstan, and Russia. This is generally consistent with recent survey findings, which show a link between smoking and lack of education in eight countries of the former Soviet Union [20].

Urban area of residence emerged as independent predictor for higher expenditure share on tobacco in Kyrgyzstan. There was no other country showing similar association. This may reflect the findings of other studies focusing on the same region and showing that smoking among men varies relatively little by area of residence $[9,19,20]$.

Although there have been studies showing that smoking rates are increased by material hardship [20], particularly unemployment $[7,8]$, our study failed to identify an independent association between unemployment and tobacco expenditure share out of $\mathrm{HH}$ total monthly spending in all countries but Kyrgyzstan. This may be determined by relative limited contribution of formal employment to $\mathrm{HH}$ income in these countries [21].

\section{Conclusion}

In absolute terms rich households tend to spend more on tobacco than poor households. However, poor HHs spend a significantly higher portion of their household budget on tobacco compared with rich HHs. HHs with more males have significantly higher expenditure share on tobacco. HHs with more educated persons have significantly lower expenditure share on tobacco.

\section{Competing interests}

The author(s) declare that they have no competing interests.

\section{Authors' contributions}

$\mathrm{MD}$ and GG conceived the research and study design, lead the analysis and drafted the manuscript. GM and AZ assisted with drafting of the manuscript. All authors read and approved the final manuscript.

\section{Acknowledgements}

This work was carried out with the grant from the International Development Research Center, Ottawa, Canada. However, the International Development Research Center cannot accept any responsibility for any information provided or views expressed.

There are no conflicts of interest to be disclosed.

We thank statistical institutes of Azerbaijan, Georgia, Kazakhstan, Kyrgyzstan, Russian Federation, and Tajikistan for granting the permission to use LSMS data sets for our research work. We are grateful to Dr. George Sakvarelidze for helping us with data transformation/management, Dr. Anna Gilmore for reviewing the manuscript and providing useful comments, and Dr. Kathy Hebert for improving the quality of written English.

\section{References}

I. World Development Report 2000/200I [http://go.world bank.org/7KWQQIWVT0]

2. De Beyer J, Lovelance C, Yurekli A: Poverty and tobacco. Tob Control 200I, 10:2I0-2II.

3. Efroymson D, Ahmed S, Townsend J, Alam SM, Dey AR, Saha R, Dhar $B$, Sujon Al, Ahmed KU, Rahman O: Hungry for tobacco: an analysis of the economic impact of tobacco consumption on the poor in Bangladesh. Tob Control 2001, 10:212-217. 
4. Arunatilake N, Opatha M: The Economics of Tobacco in Sri Lanka. Health, Nutrition and Population Discussion Paper. The World Bank 2003.

5. Ali Z, Rahman A, Rahman T: Appetite for Nicotine. An Economic Analysis of Tobacco Control in Bangladesh. World Bank. Health, Nutrition and Population Discussion Paper 2003.

6. Sayginsoy O, Yrekli, De Beyer J: Cigarette Demand, Taxation, and the Poor. A Case Study of Bulgaria. Health, Nutrition and Population Discussion Paper. The World Bank 2002.

7. Gilmore A, McKee M, Telishevska M, Rose R: Smoking in Ukraine: epidemiology and determinants. Prev Med 200I, 33:453-46I.

8. Gilmore A, McKee M, Rose R: Smoking in Belarus: evidence from a household survey. Europ J Epid 200 I, 17:245-253.

9. McKee M, Bobak M, Rose R, Shkolnikov V, Chenet L, Leon D: Patterns of smoking in Russia. Tob Control 1998, 7:22-26.

10. Laatikainen T, Vartiainen E, Puska P: Comparing smoking and smoking cessation process in the Republic of Karelia, Russia and North Karelia, Finland. J Epidemiol Community Health 1999, 53:528-534.

11. Gilmore A, Pomerleau J, McKee M, Rose R, Haerpfer CW, Rotman $D$, Tumanov S: Prevalence of smoking in 8 countries of the former Soviet Union: results from the living conditions, lifestyles and health study. Am J Public Health 2004, 94:2 177-2I 87.

12. Figini P: Inequality Measures, Equivalence Scales and Adjustment for Household Size and Composition, Working Paper No. 185, Maxwell School of Citizenship and Public Affairs, Syracuse University 2004 [http://www.lis project.org/publications/liswps/[85.pdf].

13. Kazakhstan Living Standards During the Transition, Report No. 17520-KZ. The World Bank 1998.

14. Poverty Assessment, Republic of Tajikistan, Report No. 20285-TJ. The World Bank 2000.

15. Frijters P, van Praag BMS: Estimates of poverty ratios and equivalence scales for Russia and parts of the former USSR. Tinbergen Institute, Rotterdam, Discussion Paper, nr.TI :95-I49.

16. Georgia Poverty and Income Distribution, Report No. 19348-GE, Vol.II. The World Bank 1999.

17. Hentschel J, Lanjouw P: Constructing an Indicator of Consumption for the Analysis of Poverty. Living Standards Measurement Study Working Paper No. 124. The World Bank 1996.

18. Making Transition Work for Everyone: Poverty and Inequality in Europe and Central Asia. The World Bank 2000.

19. Pudule I, Grinberga D, Kadziauskiene K, Abaravicius A, Vaask S, Robertson A, McKee M: Patterns of smoking in the Baltic Republics. J Epidemiol Community Health 1999, 53:277-282.

20. Pomerleau J, Gilmore A, McKee M, Rose R, Haerpfer CW: Determinants of smoking in eight countries of the former Soviet Union: results from the living conditions, lifestyles and health study. Addiction 2004, 99:1577-1585.

21. Johnson S, Kaufmann D, Ustenko O: Formal Employment and Survival Strategies After Communism. "Transforming Post-Communist Political Economies" [http://newton.nap.edu/html/transform/ contents.htm]

\section{Pre-publication history}

The pre-publication history for this paper can be accessed here:

http://www.biomedcentral.com/1471-2458/7/222/pre pub

\section{Publish with Bio Med Central and every} scientist can read your work free of charge

"BioMed Central will be the most significant development for disseminating the results of biomedical research in our lifetime. "

Sir Paul Nurse, Cancer Research UK

Your research papers will be:

- available free of charge to the entire biomedical community

- peer reviewed and published immediately upon acceptance

- cited in PubMed and archived on PubMed Central

- yours - you keep the copyright
BioMedcentral 